\title{
Instruments of Science and Citizenship: Science Education for Dutch Orphans During the Late Eighteenth Century
}

\author{
Lissa L. Roberts
}

Published online: 18 June 2010

(C) The Author(s) 2010. This article is published with open access at Springerlink.com

\begin{abstract}
One of the two most extensive instrument collections in the Netherlands during the second half of the eighteenth century-rivaling the much better known collection at the University of Leiden-belonged to an orphanage in The Hague that was specially established to mold hand-picked orphans into productive citizens. (The other was housed at the Mennonite Seminary in Amsterdam, for use in the education of its students.) The educational program at this orphanage, one of three established by the Fundatie van Renswoude, grew out of a marriage between the socially-oriented generosity of the wealthy Baroness van Renswoude and the pedagogical vision of the institute's director and head teacher-a vision that fit with the larger movement of oeconomic patriotism. Oeconomic patriotism, similar to 'improvement' and oeconomic movements in other European countries and their colonies, sought to tie the investigation of nature to an improvement of society's material and moral well-being. Indeed, it was argued that these two facets of society should be viewed as inseparable from each other, distinguishing the movement from more modern conceptions of economics. While a number of the key figures in this Dutch movement also became prominent Patriots during the revolutionary period at the end of the century, fighting against the House of Orange, they did not have a monopoly on oeconomic ideas of societal improvement. This is demonstrated by the fact that an explicitly pro-Orangist society, Mathesis Scientiarum Genitrix, was organized in 1785 to teach science and mathematics to poor boys and orphans for very similar reasons: to turn them into productive and useful citizens. As was the case with the Fundatie van Renswoude, a collection of instruments was assembled to help make this possible. This story is of interest because it discusses a hitherto under-examined use to which science education was put during this period, by revealing the link between such programs and the highly charged question of citizenry.
\end{abstract}

\section{L. Roberts $(\bowtie)$}

Department of Science, Technology and Policy Studies, University of Twente, POB 217,

7500 AE Enschede, The Netherlands

e-mail: 1.1.roberts@utwente.nl 


\section{Introduction}

At the core of this essay are the stories of two institutions established in the Netherlands during the late eighteenth century to educate poor and orphaned boys. The first, made possible by the large bequest left by a wealthy noblewoman, was the Fundatie van Renswoude, which operated three orphanages in The Hague, Utrecht and Delft for specially chosen boys who demonstrated promise. Second was the privately organized Leiden society Mathesis Scientiarum Genitrix (MSG). The political orientations of these two institutions differed starkly during the highly charged decades which ended one century and began the next. While members of MSG demonstrated their allegiance to the House of Orange by asking the future King Willem I to be their official patron in 1785, a number of the Fundatie's leading teachers and administrators agitated for the kinds of reform which were championed by the anti-Orange regime of the Batavian Republic. Nonetheless, they worked toward strikingly similar goals. Both placed practical mathematics and science at the centre of their programs' curriculum. And both did so with the express purpose of educating their charges to serve the public good. Placing the contextualized stories of the Fundatie van Renswoude and MSG next to each other thus offers a unique opportunity to explore how science education was appreciated across political lines in the Netherlands during a time which witnessed a full cycle from reform and revolution to war and restoration, not only in terms of stimulating knowledge production or material production for their own sakes, but also as a vehicle of socio-cultural renewal. To set the stage, this introduction will be followed by sections that discuss the context in which these stories should be placed.

In a recently published report, a European Commission committee argued for the urgency of reforming science education in the face of declining student interest. The report articulates three closely related reasons for the need to alter this trend. First, according to the report, the "[a]vailability of highly qualified science and technology professionals is a key factor for the establishment, import and success of high-tech industry in the European Union." More generally, it continues, citizens must possess increasing scientific literacy in order to understand and respond to the complex environmental, medical, economic and moral challenges that increasingly face society on both a local and global scale. Finally, the report presents science education as the key to Europe's cultural coherence. “... by giving ... [citizens] the opportunity to develop critical thinking and scientific reasoning... science education helps fighting [sic] misjudgments and reinforcing [sic] our common culture based on rational thinking." (Science Education Now 2007, pp. 6-7)

Two closely related characteristics of this document make it of special interest in relation to this essay. The first is that it broadly ties science education to concern for issues ranging from economic growth and environmental sustainability to social stability, moral rectitude and cultural cohesion. Second is that its rhetoric characterizes science with the twin terms of rationality and instrumentality, and projects an image of European culture as innately rational and progress oriented. What holds the report together, in other words, is a vision of science as the cornerstone of modern western culture which served and must continue to serve as the motor of both material and moral progress. It is not my purpose here to subject this portrayal to critique. Rather, I want to draw attention to the fact that this claim which links scientific education to socio-cultural concerns beyond economic and intellectual growth is strongly rooted in Enlightenment ideology. ${ }^{1}$ From this perspective,

\footnotetext{
1 That the coupling of scientific, social and moral progress was an outstanding theme during the Enlightenment, including by those who offered doubts, hardly needs a footnote. Diderot and d'Alembert's Encyclopédie stands out as perhaps its greatest monument.
} 
then, focusing on scientific education only for its own sake or in relation to economic growth is just half the story.

This is not only a question of omission, however. By forgetting the moral concerns that lay at the heart of many science education programs and discussions during the eighteenth century and since, some historians have been led to misread the past. This is particularly so in the case of historians who seek to explain the Netherlands' belated process of industrialization, relative to Great Britain and Belgium, as rooted in Dutch society's declining interest and involvement in science and science education during the second half of the eighteenth century. A number of (especially economic) historians have accepted the view that modern technological and economic development are rooted in the spread and application of Newtonian mechanics, as most elegantly expressed in the work of Margaret Jacob. (Jacob 1997, pp. 141-154) ${ }^{2}$ This trend has led to both a narrow definition of 'science' and 'the culture of science', as well as to an equally narrow vision of the historical relation between material production and knowledge production. (Roberts et al. 2007) For while it is certainly the case that Dutch universities ceased to be the leading international centers for the study of experimental philosophy and medicine during the second half of the century, the investigation of nature continued to be valued in the Netherlands throughout the century, for reasons that went beyond the growth of scientific knowledge for its own sake, the goals of 'polite' amateur learning, and narrowly construed interests in material productivity and economic growth.

Indeed, a good deal of concern for the teaching of science, and education more generally in the Netherlands during the second half of the eighteenth century, was linked to what the Dutch called 'oeconomische patriotisme', akin to what one might find in oeconomic and 'improvement' societies throughout Europe. ${ }^{3}$ The word oeconomie did not actually find its way into Dutch dictionaries until the eighteenth century. But its appearance should not be seen as signalling the birth of modern economic thinking. Rather, it drew on its etymological origins, linking market activities to a vision of society as a (domestic) household. ${ }^{4}$ In such a situation, material productivity could not be considered as an

\footnotetext{
${ }^{2}$ For a critical variation, see Davids (2005, pp. 330-336), in which he argues that the problem was not inattention to science, but insufficient interplay between 'science' and 'technology'.

3 There exists as yet no overarching study of this important Enlightenment movement, whose variegations were colored by local socio-political characteristics. Hence, for example, German variants developed within the context of government-sponsored cameralism, while Swiss and Dutch oeconomic societies were more engaged with the ideals and actualities of their local republican contexts and English 'improvers' operated in a context colored at least partially by the ways in which market-driven entrepreneurialism bridged the traditional gap between rural and urban forms of productivity (see, for example, Lowood 1991; Wakefield 2009; Kapossy 2007; Roberts 2006; Mijnhardt 1988). No study of this phenomenon would be complete without mentioning its global reach, both in terms of the ways in which global exchanges were taken up by European oeconomists and in terms of the establishment of oeconomic societies and activities outside Europe. On the first, see for example, Koerner (1999).

${ }^{4}$ Etymologically, the original Greek oikos and its Latin equivalent refer either to household management or ecclesiastical dispensation, explaining the initial Dutch translation as huishoudkunde. While the word oeconomie had acquired a broader meaning by the seventeenth century, referring to the orderly management of a larger community's resources (hence the Dutch staathuishoudkunde), it continued to carry with it a sense of the moral responsibility entailed in the organization and management of familial resources (see Shannot 1736, p. 359; Arsy 1682; Sewel 1766, vol. I, p. 529 and vol. II, p. 350).

The introduction, definition and applied use of the term oeconomie in Dutch during the eighteenth century helps explain why the amorality of Adam Smith's economic views in Wealth of Nations originally found little fertile ground in the Netherlands, as opposed to his Theory of Moral Sentiments (see Kloek and Mijnhardt 2001, p. 301).
} 
autonomous goal; for the benefit of society, it had always to be accompanied by the goals of virtuous behavior and a sense of moral responsibility. ${ }^{5}$

This helps to explain why, across Europe and beyond, the eighteenth century is full of examples in which improvements in agriculture and manufacture alike were spurred by individuals and organizations who were not solely motivated by self-enrichment in the financial sense. More specific to this essay, it helps us understand why two of the largest scientific instrument and model collections in the Netherlands during the eighteenth century belonged to institutions which were not primarily interested in the advancement of science for its own sake and whose aims were other than (economically understood) profit maximization. The Mennonite Seminary in Amsterdam, which housed an enviable collection, included experimental philosophy in its curriculum so as to prepare Mennonite preachers for the task of linking an understanding of this world with concern for the world to come. ${ }^{6}$ The other institution in question was an orphanage established in The Hague with an educational programme intended to nurture promising orphans whose talents would otherwise be lost to society. Along with fraternal institutions in Delft and Utrecht, this orphanage was funded by the Fundatie van Renswoude, which was capitalized by the bequest of a wealthy aristocratic widow, and staffed by a group of dedicated and socially engaged teachers. ${ }^{7}$

What brings these two institutions together, beyond the fact that they invested in science education, is that they did so for reasons that help reveal how interest in and involvement with science were undergirded by a wide range of meanings attached to the concept of utility, recognized as a central tenet of the Dutch Enlightenment (Roberts 1999; Mijnhardt 1987; Mijnhardt 1998; Mijnhardt and Kloek 2001). For some, studying nature was useful for what it taught about the creative greatness and goodness of god. For others, it was a necessary first step toward being able to control nature for material or social benefit. For some, an understanding of natural laws buttressed a drive to understand and reform the laws of society. Others sought to weave science education into a program that somehow tied meritocratic ideals to conservative political allegiance. In other words, thanks to the variegated understanding of and support for utility, the Dutch found it possible to disagree about politics while agreeing about the desirability and meritocratic goals of science education. $^{8}$

This can perhaps best be seen by setting the Fundatie van Renswoude's program alongside that of a contemporary organization established in Leiden, the amateur society Mathesis Scientiarum Genitrix (MSG), which also aimed to improve the lives of select orphans through the medium of science education. As mentioned at the beginning of this essay, these two organizations manifested rather different politics, but never wavered from their commitment to enrich society by educating its orphans. This study allows us, then, to go beyond the rhetoric of political opposition voiced during the turbulent years of

\footnotetext{
${ }^{5}$ Contrast this view with the otherwise informative work of the social and economic historian $\mathrm{H}$. Van den Eerenbeemt, who develops a claim that the Dutch Enlightenment was marked by a "marriage" between philanthropy and economics. Reference to marriage rather than (perceived) unity is to read a modern, liberal conception of 'economics' back into an inappropriate context (see e.g. Van den Eerenbeemt 1972, 1977).

${ }^{6}$ On the Mennonite instrument cabinet, see Zuidervaart (2006).

${ }^{7}$ For the most recent and complete study of the fundatie, see Gaemers (2004).

8 In this regard, the concept 'utility' can be considered as a boundary object. See Star and Griesemer (1989): "Boundary objects are objects which are both plastic enough to adapt to local needs and the constraints of the several parties employing them, yet robust enough to maintain a common identity across sites...They have different meanings in different social worlds but their structure is common enough to more than one world to make them recognizable, a means of translation” p. 393. See also Daston (1999).
} 
revolution and war at the close of the eighteenth century, to examine a practical current of cultural continuity. Whether Orangist or Patriot, broad sectors of Dutch society could be counted on to support the goals of moral citizenship. For individuals such as the members of MSG and those involved with the Fundatie van Renswoude this entailed organizing and supporting educational opportunities for underprivileged children.

These two institutions, examined in the penultimate sections of this essay, reveal further how science and technology were harnessed to develop the talents of promising Dutch orphans for public benefit, thereby informing us about the place given science and technology in Dutch culture more generally. Based on a formula that tied meritocracy to social benefit through the medium of scientific and technological instruction, select orphans were taught mathematics, physics, architecture, instrument-making, the surgeon's art and various permutations of what we now broadly call engineering, both to realize their individual potential and to tap their talents for the good of the nation.

While, as stated, oeconomic and improvement movements were widespread in Europe during the second half of the eighteenth century, the specifically Dutch history of having to contend with threats posed by the natural habitat left its mark on the movement's contours in the Netherlands. Dutch survival historically depended, that is to say, on shaping the physical environment and making the most of limited resources. (Lambert 1971) If this meant centuries of innovative water management and land reclamation projects, it also required social and cultural cooperation, even when political agreement was not possible. ${ }^{9}$ Some argued that it further required nourishing talent, wherever it might be found, for the sake of national moral and material progress. Hopeful that promising young minds could be productively cultivated through the application of science and technology, just as the Netherlands' originally savage landscape had been, these reformers tied science and technology to the meritocratic enhancement of Dutch culture and society.

\subsection{Moral Citizenship and Education in the Netherlands ${ }^{10}$}

When Dutch reform advocates spoke of reinvigorating their 'fatherland' during the second half of the eighteenth century, they generally took this paternal metaphor to include a vision of the 'natural' social order and what was needed to maintain its health and stability in materially difficult times. The lower classes had a right to gainful employment, they argued, but also a duty to adhere to what many current-day politicians continue to refer to as 'Dutch norms and values'. ${ }^{11}$ This meant first that the potential productivity of the poor-especially in urban areas that were suffering from growing overseas competition during the eighteenth century-should be tapped. If this was often expressed in positive terms as the key to alleviating poverty and re-establishing the Netherlands as an international centre of manufacture and trade, Hendrik Herman van den Heuvel-founder of the important reforming society Oeconomische Tak (the "Oeconomic Branch," established in 1777 as an offshoot of the Hollandsche Maatschappij der Wetenschappen [Dutch Society of Science] to encourage material and moral recovery) and editor of the spectatorial journal

\footnotetext{
9 "Few countries exist where the hand of man has exerted a greater formative influence in the shaping of the landscape". Lambert (1971), preface.

${ }^{10}$ For a general introduction to this topic, see Los (2005), especially Chap. 9.

11 Cornelis Ris, founder of the Vaderlandsche Maatschappij van Reederij en Koophandel (Fatherlandic Shipping and Commerce Company) in the town of Hoorn, for example, repeatedly described characteristics such as decency, humility, thrift, honesty and sincerity as traditional Dutch qualities. See, for example, Ris (1777, pp. 16, 19).
} 
De Borger - was more blunt. He strongly advised matching education to a child's social station, lest the poor come to think that they were too good to work with their hands. Too much education, he warned, was a threat to social stability (De Borger, 2 (October 1778): 337-341). ${ }^{12}$ In this, his views were consonant with those voiced by a number of 'enlightened' contemporaries throughout Europe. As discussed by Daniel Mornet in his classic study on the intellectual origins of the French Revolution, the French philosophes' ideal of popular education was predominantly to "make more useful men, not more thoughtful ones". Hence could a well-trained workforce augment the nation's prosperity without "inverting the order of things". 13

Utility dictated for Van den Heuvel that the poor imbibe the values of hard work and civic virtue so as to render them materially productive and socio-politically passive. This can be seen, for example, in proposals that were floated within the Oeconomische Tak to train poor youth for service at sea. Traditionally a maritime nation, the Netherlands was losing ground to England militarily and commercially during the second half of the eighteenth century, partly due to lack of naval manpower. Some society members thought the answer was to organize an institute for maritime training, as English counterparts had done in 1756, but the society's central committee decided it was more efficient simply to offer monetary awards to boys who signed up for on-the-job training. (Titsingh 1780) When such a school was nonetheless founded in Amsterdam by private subscription in 1785, the society did offer limited financial support. (Bierens de Haan 1952, pp. 67-70) The emphasis remained fixed, however, on immediately perceived social benefit rather than popular enlightenment.

Other initiatives, set in motion by various municipalities and private parties during this period, tended to couple the establishment of workhouses for textile manufacture, as well as for products ranging from wallpaper to porcelain, with various incentives (either positive or punitive) to convert the 'idle' poor into productive workers (Van den Eerenbeemt 1977). If domestic (a term that reminds us of the oeconomic equation of the nation with a familial household) output could thus be increased, reformers believed, Dutch society would once again flourish in terms of widespread material wealth and the kind of happiness found in moral rectitude; simply put, a return to the republic's 'golden age'. For the poor, however, the future looked somewhat less golden. Workdays in such institutions were long and often structured to include training programs for the young, who learned manual skills such as spinning and embroidery, along with basic reading, writing, arithmetic and the fundamentals of moral religion. The general goal was to train an army of citizens, through the propagation of industriousness, to accept their place in the social order while contributing to the moral and material good of the nation as a whole. ${ }^{14}$

This makes the educational and professional opportunities afforded orphans by the Fundatie van Renswoude and MSG, as will be discussed later in this essay, seem all the more striking. But, explaining the presence of these two institutions is not simply a matter

\footnotetext{
12 Hake labels oeconomic patriots such as Van den Heuvel and Ris as 'conservative' for this stance, which leads him to argue more generally that oeconomic patriotism was a conservative faction within the more general Patriot movement. Hake (2004, p. 20). But, as stated below, Ris became so active in the Patriot movement that he had to flee his home town in 1787 when pro-Orangist forces gained political control of the area.

13 First quotation from Mornet (1967, p. 421). Second quotation from François Philippe Gourdin, "De l'éducation physique et morale considerée relativement à la place que doivent occuper les Enfans dans l'ordre de la Société" (Lyon 1779) cited in Chisick (1981, p. 173).

14 Reformers such as Cornelis Ris explicitly used the term 'citizen' to refer to the entire Dutch population. See Ibid., passim.
} 
of contrasting proclaimed opposites such as Enlightenment thinking and revolutionary ideology (both organizations were established too early, in any event, for this to be the case) or Orangist conservatism and Patriot progressivism. Ultimately, we can best understand them as manifesting a small but telling facet of the Netherland's complexly hewn culture of utility — one that tied science and technology to the narrowly applied ideals of meritocracy.

Even before turning to the Fundatie and MSG, however, we can see just how complex this culture was by recognizing the role played by the House of Orange in supporting efforts to revive Dutch productivity during the late eighteenth century, as well as after its establishment as the Netherlands' royal house after the fall of Napoleon. When the reforming society Oeconomische Tak, original home of Dutch oeconomic patriotism, was established in 1777 to stimulate a fusion of material and moral progress in the Netherlands, it did so with Stadholder Willem V as its official patron. Not only did he announce his intention henceforth to prefer domestic products over imports, a basic tenet of the society, he and his family put their money where their mouths were by supporting various ventures intended to produce and bring domestic goods to market. They became major stockholders, for example, in Cornelis Ris' Vaderlandsche Maatschappij van Reederij en Koophandel (Fatherlands Shipping and Commerce Company), which oversaw a network of production centers that specialized in products ranging from whaling ships to stockings and painted wallpaper as well as administering a school in which poor children were taught religious and moral responsibility, reading, writing, arithmetic and the sorts of basic manual skills with which they could be put to work.

Ris was pleased to have such highly-placed backing, but this didn't stop him from becoming active in the local Patriotic Society of Hoorn-so active, in fact, that he had to flee the city in 1787 following an Orangist victory there (Kooijmans 1985, p. 195). The stadholder's family similarly bought shares in the porcelain factory and school set up in 1774 by the pastor Johannes de Mol in the small town of Loosdrecht. Further, Willem V made a point of paying official visits to sites that promised oeconomic progress, whether a semi-mechanized cloth factory in Amersfoort in 1777, a newly erected steam engine near Rotterdam in 1790 or a workhouse in Groningen in 1791 (Roberts 2004; Van den Eerenbeemt 1977, pp. 40, 93, 98-114).

When we combine this with the fact that Orangist financiers, such as the Hope family (owners of one of Europe's largest private banking organizations), organized and underwrote portions of the financing for such ventures, two things become apparent. First, no easy contrast or opposition between (oeconomic) Patriots and Orangists is possible in the realm of supporting oeconomic reform-an important vehicle for furthering the drive toward moral citizenship in the Netherlands. Second, the ability to share such sociocultural goals across an apparent political divide and even cooperate in seeking their attainment did not end with the onset of revolution. Traces of this shared urge toward oeconomic reform could still be found in the Netherlands long after Batavians and Bonapartists alike were replaced by the establishment of a kingdom under Willem I (son of Stadholder Willem V). Consider, for example, the king's supportive stance regarding postrevolutionary Dutch industry and commerce, which can be seen as a partial outgrowth of the examples given by his father and 'oeconomic patriots' alike, as well as a partial continuation of policies previously enacted by King Louis Napoleon. Not only did King Willem I serve as official patron of MSG from its inception in 1785 (before he became king, that is), a position he resumed upon his return to the Netherlands in 1813 and continued to hold until his death in 1843. He was also a major stockholder in the Nederlandsche Handel Maatschappij (Dutch Trading Company-established to stimulate 
Dutch commerce, employment and overseas trade) and supported initiatives such as the series of weaving schools set up by Thomas Ainsworth in the early 1830s to provide employment and stimulate textile production in the Netherlands following separation with Belgium (Coeverden 1983). Clearly the historical circumstances-including economic (as opposed to oeconomic) policies and practices-were different by this time, but it makes more sense in this context to speak of the Dutch culture of utility having undergone a complex process of evolution than to refer to the revolutionary period as constituting a watershed.

\section{An Alternative View}

As we have now seen, a number of prominent voices and initiatives in the Netherlands thus sought to mediate the challenges of progress and social control through programs that trained the poor to be materially productive, morally upright and socio-politically passive. If this was a fairly typical manifestation of Enlightenment thinking at the time, the physician and amateur historian Simon Stijl (1731-1804) offered a different perspective on the way in which educating the poor should serve the common good. In 1774 he published his widely read work, De opkomst en bloei van de Republiek der Vereenigde Nederlanden (The Rise and Flourishing of the United Dutch Republic), in which he offered a different view of the relationship between public education and social utility. Like many Dutch contemporaries, Stijl placed the broadly perceived problem of national decline in a moral context and argued that the source of his compatriots' woes was that they had been seduced by decadent French mores. Traditional values and industriousness had given way to materialism and idle sophistication (Stijl 1774, especially p. 687). ${ }^{15}$ According to Stijl, the key to national recovery was education... but of a certain kind. He advocated establishing a society to educate poor children, especially orphans.

To indicate what he had in mind, Stijl asked, "Why is mathematics, which is so useful for guiding human understanding, never counted among the characteristics of a good upbringing?" ${ }^{16}$ Unlike his French counterparts, Stijl declared, he was not afraid of teaching children to think, no matter how unfortunate their circumstances. It was in society's best interest, he asserted, to help all its youth acquire the combined virtues of modesty, reflection and productivity. An upstanding cadre of lawyers, doctors, mathematicians, artists and craftsmen could thus be formed, who would bring credit to their fatherland as they helped to improve its material and moral conditions. ${ }^{17}$ Rather than destabilize the

\footnotetext{
15 For biographical background and a discussion of Stijl's "Enlightenment" style of history writing, see Smitkamp (1950). While the explanation of Dutch moral decline through "Frenchification" was fairly common, it is interesting to note a variation on the theme offered by Stijl's conservative contemporary Elie Luzac. In addition to his more general social criticisms, Luzac claimed that Dutch natural philosophy was suffering from the rage for "French science" by which he meant the "superficiality" of the Encyclopédistes and the kind of physique amusante practiced by the Abbé Nollet. See, for example, various remarks in Luzac (1759, vol. III), passim.

16 "Waarom wordt de Wiskunst, die so nuttig is om aan het verstand eene geregelde leiding te geeven, nooit onder de punten van een fraaie opvoeding geteld?" (Stijl 1774, p. 689). For trends in society membership and the distinction between dilettante and reforming societies, see Mijnhardt (1988). For Dutch spectatorial literature, see Johannes (1995).

17 Contrast Stijl's plan with more usual programs for the "education" of orphans, which often amounted to no more than exploiting their labour (Groenveld et al. 1997; Hoker 1982).
} 
social order, orphans gifted enough to achieve these goals would strengthen the society in which they lived.

\subsection{Educating Orphans}

Before we finally turn to the special educational programs organized for orphans by the Fundatie van Renswoude and MSG, providing a sketch of the kind of life and learning experienced by most Dutch orphans is in order. The Heilige Geest orphanage in Leiden, from which students were recruited for MSG, provides a good example with which to begin. In 1777 nearby Leiden University's physics professor Jean Nicolas Sebastian Allamand had four model steam engines from the university's instrument collection put on display in the orphanage's courtyard for student lectures and public demonstrations. Despite the display's highly innovative character, no one at the orphanage recorded their reaction. Were orphans present at demonstrations? How did they react to university students in their midst? Were they also 'on display' when visitors came to see the orphanage and its advertised engines? ${ }^{18}$ Meeting university students and tourists might have held up a sort of cultural mirror in which orphans could see their images reflected against the perception of those who observed them and their surroundings. But no recorded testimony exists to tell us how orphans perceived this complicated set of cultural relations.

We do, however, know how orphans were educated at the Heilige Geest orphanage and in the Netherlands generally. ${ }^{19}$ First, like all Dutch orphans, they were required to wear uniforms which were coloured to match the coat of arms of the city that housed their institution. Heilige Geest orphans thus dressed in red with blue, black and white accessories, and a patch on the left sleeve to represent Leiden's municipal shield (Mieris 1784, vol. III, p. 105). Whether inside or outside the orphanage, then, the status of Dutch orphans was clearly marked. Daily life and future prospects were similarly regimented, making their place and expectations equally clear.

Indeed, regimentation was a key pedagogical tool. Consider this primary rule of conduct: "that during the day and evening school time, no one may leave his place without the teacher's consent, nor is anyone allowed to ask questions or recite their lessons out loud, but rather to be so quiet that nothing can be heard". This disciplined atmosphere coupled with an overriding emphasis on religion (all the books in the orphanage library, for example, dealt with religious subjects) were meant to prepare orphans for a life of docile acceptance. $^{20}$

The first thing they had to accept was a fixed schedule. Younger children had lessons every weekday from nine until twelve and two until five; lessons on Saturdays went from nine until eleven. The time was spent reading and writing, mostly in relation to catechism, and basic arithmetic. Three afternoons a week were deemed enough for older children who worked doing laundry, sewing and the like. Classes for older boys apprenticed in crafts as textile manufacturing, plumbing, smithing, painting and glass making, were held in their

\footnotetext{
18 We should remember here both that an article about the placement of one of the machines in the courtyard appeared on the front page of the Leidse Courant, 22 June 1777 and that visits to institutions such as orphanages and asylums were common forms of entertainment (see Roberts 2007).

19 For a good introductory overview, see Groenveld et al. (1997), especially pp. 194-215.

20 "Dat geduurende de dag en Avondschooltijd, niemand van zijn plaats mag opstaan zonder consent van de meester, als ook dat niemand vermag iets 't zij vragens of lessen verstaanbaar te leeren, maar so stil dat er niets van gehoord kan worden". Archief Heilige Geest Weeshuis, Leiden municipal archives, \#3743. The catalogue of library books is found in \#3744. Not everyone internalized this lesson, of course. The records of the orphanage contain numerous accounts of runaways and other disciplinary problems.
} 
workshops. And for a final group of older girls whose work kept them busy all day, school was held at night from seven to nine. Lessons in penmanship, number recognition, and Christian morality remained an organized and organizing part of every orphan's life as long as they lived under the orphanage's care. ${ }^{21}$

\section{Mathesis Scientiarum Genitrix}

If anything, such a disciplined environment seems more conducive to deadening imagination and curiosity than to fostering them. But in 1786, potential salvation came for a small number of orphans at the Heilige Geest Orphanage. A local society dedicated to teaching working class children mathematics offered to educate the orphanage's most promising (male) students on a yearly basis at its own expense. ${ }^{22}$ Though its founders neither belonged to the Oeconomische Tak nor cited Simon Stijl, their society's history straddled what the one practiced and the other preached. The Genootschap der beschouwende en werkdadige wiskunde, onder de zinspreuk: "Mathesis Scientiarum Genitrix" (Society for theoretical and practical mathematics, under the motto "mathematics gives birth to science/knowledge") was established in Leiden in 1785, thanks especially to the efforts of Pieter van Campen, surveyor, mathematics teacher, wine gauger, captain in the Lydsche Oranje Schutterij (Leiden Orangist Militia), and author of books ranging in subject from algebra and mechanics to the construction of self-powered water mills and (bad) poetry. Many of the society's members shared his Orangist sympathies, leading them to seek (successfully) the patronage of the prince who ultimately became King Willem I. Under his official protection, they set out to serve their fatherland by instructing " $d e$ kinderen des volks" in mathematics and its practical applications. In 1786, they decided to include a small number of orphans in the society's student population. ${ }^{23}$

Originally, the society offered a mixed program. Students from Leiden University and the city's middle class were trained to help teach fortification design, the mathematical analysis of projectiles, and navigational techniques to working class boys in the hopes of making them fit for military service or life at sea. If this seems in line with the Oeconomische Tak's orientation, the curriculum offered to orphans promised more. Instead of being channelled toward a career in the army or at sea, orphans were introduced more broadly to the principles of mathematics, architecture, experimental physics, and drawing. Too little remains in the archives to indicate whether the primary goal of this program was to train skilled craftsmen or expand the orphans' horizons. A class schedule from 1792 which does still exist includes courses in arithmetic, seamanship, mechanical engineering (werktuigkunde), drawing, geography, architecture, experimental physics and algebra. We know further that society members sought to maintain the program's educational level by organizing a subsidiary society in which they practiced operating scientific instruments and built machine models that could then be shared with the children. Finally, courses were

\footnotetext{
21 Ibid., \#3743 and \#3865. The only exception to these requirements was for orphans who were placed in service, either military, naval or with the West or East Indies Companies. See \#221 and \#3887.

${ }^{22}$ For more general discussion of mathematical education at this time, see Beckers (2003).

23 For biographical information on Pieter van Campen, see Nieuw Nederlandsch Biografisch Woordenboek, 1924, vol. 6, columns 260-261. Other founders included Arnoldus van Gennep, law student at University of Leiden, J. Reinier, theology student, Pieter Rijk, bricklayer and teacher, A. de Bruine de Neve, medical student, and Betholomeus van den Broek, sculptor and teacher. Van den Broek taught drawing and draughting for the society for some 50 years before retiring. The quoted phrase is from Bemmelen (1910, p. 41). For the agreement between the society and the orphanage, see Archief Heilige Geest Weeshuis, \#3757.
} 
held for a time in the same room as that which housed the artist Frans van Mieris' Maatschappij van Schilder-en Teekenkunde (Society for the Arts of Painting and Drawing). One can only imagine the impact of such encounters and surroundings. ${ }^{24}$

In 1802 the orphans' curriculum was adopted for everyone and university and middle class students were no longer trained to teach their lower-class piers (Dijk 1885, p. 17). MSG's Orangist members might have been less inclined to train sailors and soldiers for the Batavian Republic, but local politics undoubtedly also had something to do with this newly chosen direction. As early as 1788 Allamand's successor at Leiden University, C.H. Damen, complained about the society's program and pretensions. Threatening action to protect his own academic turf and clientele, Damen also criticized society members for thinking they could effectively teach military and navigational arts without having experience themselves and without including a practicum in their lessons. No war was ever won or sea ever crossed by reading a book, he averred (p. 14). ${ }^{25}$

Damen was less damning of the courses offered by the society to a select group of orphans. It never hurt anyone to learn how things work and it might actually happen that an orphan would thereby be led to rise above his circumstances. But even here Damen remained less than optimistic. He argued that few orphans had the attitude and aptitude needed to succeed as an architect or millwright. As if to echo his words, the only surviving letters from the society's teachers to the orphanage from this period are filled with disparaging remarks about orphans' lack of ability and commitment. ${ }^{26}$

This did not keep the society from carrying on with its self-appointed mission, however, nor from attaining both a good reputation and social standing for its work. Public examinations, for example, advertised students' ability to calculate complicated sums in their heads. Students learned from both published textbooks and handbooks written specially by society members. They studied experimental physics and mechanical engineering (werktuigkunde) through experimental demonstrations with the society's collection of instruments and mechanical models, as well as by building their own model machines. As the nineteenth century progressed, MSG carried on, firmly anchored by its dual allegiance to monarchy and meritocracy. ${ }^{27}$

\section{The Fundatie Van Renswoude}

The evidence that Damen drew on for his somber picture of orphans' educational achievements came from his (however biased) familiarity with the Fundatie van Renswoude. In 1754, Maria Duyst van Voorhout, vrijvrouwe (baroness) van Renswoude died, leaving two legacies. ${ }^{28}$ The first was a sum of 500,000 guilders to provide advanced education for select orphans from the Municipal Orphanage of The Hague, the Reformed Orphanage of Delft, and the Stadsambachtskinderhuis of Utrecht. The second is the

\footnotetext{
${ }^{24}$ For the class schedule see Peeperkorn (1985, p. 73). The sub-society mentioned was originally named the Wis- en werktuigkundig genootschap onder de spreuk: kunst word door oefening aangekweekt. It continued to exist until 1840 as the Physisch Genootschap. For mention of the MSG's relation with Frans van Mieris, see Ibid., p. 27.

25 For more details, see Archief Koninklijk Genootschap 'Mathesis Scientiarum Genitrix', Leiden municipal archives.

26 Archief Heilige Geest Weeshuis, \#3758.

27 See Peeperkorn (1985) for nineteenth and twentieth century.

${ }^{28}$ For biographical information, see Booy and Engel (1985, pp. 19-22).
} 
historical presence of a Dutch noblewoman who collaborated with natural philosophers and practiced a kind of philanthropy usually associated with late eighteenth-century reforming societies. $^{29}$

Together these legacies point to how complicated the socio-political map of eighteenthcentury Dutch culture was. Simon Stijl's patriotism led him in the late eighteenth century to combine his call for popular education with a Montesquieuian program of mixed government in which Stadholder, regents and "the people" formed a productively balanced whole (Smitkamp 1950, p. 216). Members of Mathesis Scientiarum Genitrix, on the other hand, linked Orangist sympathies with Enlightenment ideals even during revolutionary times. Decades earlier, the Vrijvrouwe van Renswoude shared the disdain of a number of her fellow regent-aristocrats for the House of Orange while she showed her intellectual and economic independence by endowing a unique set of educational institutions for orphans rather than leaving the whole of her fortune to relatives (Langenbach 1995).

Van Voorhout was explicit about the sort of education she wanted specially chosen orphans to receive. They were to be trained in "mathematics and physics, drawing or painting, sculpting or carving, building strong dikes to protect our land from heavy inundations of water, and similar liberal arts. ${ }^{30}$ In practice this meant that the educational program was divided in two. Internally, Fundatie pupils followed a curriculum which included mathematics instruction (mathesis), drawing and catechism lessons. Pupils further studied foreign languages, penmanship, current events and geography. Outside the foundation, pupils received individualized training, in keeping with the career for which they were being prepared. In sum, their education was intended to prepare them for useful lives as watchmakers, instrument makers, surveyors, engineers, architects, surgeons, artists, teachers and military officers. A series of portraits made of the Foundation's first students in Utrecht, captured the promise this education bestowed on the boys by portraying them with the instruments of their chosen trade in hand. ${ }^{31}$ So was Jan Weteling, who specialized in navigation and surveying and who, after spending time in service of the Dutch East Indies Company, became a school master in later life, pictured holding an astrolabe (pp. 37-39). Jan Wormerus Raven, whose study in surveying and engineering ultimately led to his appointment as inspector general of Water Management (inspecteur-generaal van Waterstaat) and mayor of the Zeeland town of Sas van Gent, posed with a Holland circle in his hands (pp. 56-58). And Hendrik Groenendaal, whose training as an instrument maker included a temporary apprenticeship in Paris and who later worked making instruments for Martinus van Marum and Teylers Museum, chose to be portrayed with a microscope he had made (pp. 84-86).

The foundation was also interested in raising its students' social and cultural horizons. Foundation orphans wore a specially designed uniform to distinguish them from those who remained in the institutions from which they came. Beside academic courses, they learned dancing, the niceties of polite conversation and table manners. And students were

\footnotetext{
29 The Vrijvrouwe van Renswoude apparently met Antonie Van Leeuwenhoek while growing up in Delft and retained a friendship with him in later years, though the only letters still extent to evidence a relationship are those written by Van Leeuwenhoek to her husband. These letters contain details of microscopic observations made in her home. See Alle de Brieven van Antonie van Leeuwenhoek (1979, vol. 10, p. 161). See also Wall (1760, p. 18).

30 “...Mathesis, teekenen of schilderkonst, Beeldhouwen of Beeldsnijden, oeffeningen in sware Dijkagien tot behoudinge van ons Landt tegens sware overstromingen van 't water, of dergelijke Libere Konsten". This portion of her testament is quoted in Langenbach (1991, p. 10). I leave the questions of artistic and surgical training largely aside (which do not alter my argument) because of space limitations.

31 Ibid. This book is based on an exhibition held in January 1991 at the Centraal Museum, Utrecht.
} 
encouraged to learn about the creative arts and to read as extensively as possible. The idea was that they should they not only serve society, but that they should politely fit into it as well.

These were boys who would never have attended university on their own, yet they were exposed to many of the same authors and instruments as university students. An inventory of the Delft library from 1790, for example, lists the titles of some 200 study books. Students were further supported to purchase their own books. Books in Dutch, Latin, French, and German on subjects including natural history, mathematics, astronomy, mechanics, military arts, fortification building, geography, architecture, shipbuilding, machine building, navigation, and surveying appeared in the library and student collections, indicating that students had a broad range of interests and working knowledge of more than one language. ${ }^{32}$

The physics cabinets of the three foundations were well enough equipped to rival, if not surpass, that of Leiden University. In 1787, for example, the Delft foundation bought a large portion of Leiden Professor Allamand's private instrument collection when he died. An inventory taken immediately after the purchase lists some 265 instruments spread over eight categories: mechanical and machine models; hydrostatic and hydraulic instruments; instruments for experimenting with air, fire and magnetism, light, and electricity; instruments for astronomy and navigation as well as sundials; and, finally, measuring devices and artillery instruments. ${ }^{33}$

In The Hague, the situation was even more lavish. An inventory of its collection from 1802 fills seventy-five pages and includes 667 separate entries, some of which were items purchased from well known London instrument makers and others crafted by foundation students (Florijn 1802). One of the entries, for example, described what must have been an impressive copper and ivory orrery made by the London instrument maker E. Wright, but powered by a mechanism made by one of the orphans, Johannes Anthonie van Baarda (p. 6). Others included a wide range of measuring devices, globes made by the surveyor and geographer to Queen Anne, John Senex, an octant from John Hadley's hand, several balances and devices for demonstrating physical principles which were discussed by 's Gravesande, Nollet, Desaguliers and Musschenbroek (relevant page numbers are given in the inventory). ${ }^{34}$ So too were detailed working models of various machines, mills and constructions such as bridges and building elements part of the collection as were a number of apparatus for use in the study of water management. Both English and domestically made air pumps were present, along with various items for studying air(s), sound and heat. Of special interest in this last category were two items discussed by 's Gravesande-an aeolipile and a steam-driven wagon-both of which demonstrated the basic principles and power of controlled steam. Optical instruments also abounded as did devices for demonstrating static electricity and gravity, making this a highly exemplary collection both in terms of its size and breadth of coverage. Foundation students were indeed a lucky lot.

The institution's governors initially budgeted 3,000 guilders annually (and more, as needed) for the purchase of instruments. The amount tapered off as the instrument collection grew, but results remained impressive. To compare, Leiden University spent some 10,000 guilders on instruments for the university physics cabinet for the period 1742-1811, leaving it with 410 items. During the same period, about 25,000 guilders were spent on the

\footnotetext{
32 See Booy and Engel (1985, appendix 1; pp. 275-283) for a complete list of titles.

33 Ibid., appendix 2 (pp. 285-290) lists the entire inventory of the Delft collection. For The Hague, see Florijn (1802, p. 47).

34 The texts cited were Gravesande (1746), Nollet (1759), Desaguliers (1751) and Musschenbroek (1762).
} 
Teylers Museum collection in Haarlem, where Martinus van Marum sought to turn the museum into an international center for natural philosophical research. Given these figures, the Swedish astronomer and diarist Bengt Ferrner had cause to predict that, within a few years of his visit in 1759, the foundation in The Hague would house the best instrument collection in the Netherlands. ${ }^{35}$

The precise details of how Van Voorhout's instructions were to be carried out were left to local committees. Hence, the institutions in Delft, Utrecht and The Hague differed from each other in a variety of ways that at least partially reflected the differences among the three orphanages from which Van Renswoude charges came. But they shared a basis in mathematics and experimental physics, a special emphasis on fields that related to water and land management along with the making of precision instruments, and an apprenticeship system that placed students in the best possible place to learn their chosen trade. These facts are revealing in a number of ways. They tell us what the governing regents considered necessary to prepare talented boys for a life combining personal development and public service. We see also their commitment to bolstering the Dutch tradition of seeking security and prosperity through engineering-whether of the land- or waterscape.

Thanks to the enlightened largesse of their benefactress, then, Fundatie van Renswoude students were exposed to the latest innovations in the arts and sciences. If they pursued this striking opportunity, they stood to realize the utilitarian and meritocratic ideal that authors such as Stijl wrote about and so many others dreamed of. And, contrary to what Damen reported in his disparaging letters to MSG, a number of orphans did precisely this, obtaining university degrees in a few cases and rising through the ranks of organizations such as the Dutch East Indies Company, private engineering firms and public water boards. Teachers might have complained about some students' lack of diligence and some students might not have completed the program, but many of those who did went onto enjoy productive careers. Of the 42 pupils admitted to the Utrecht program between 1761 and 1795, for example, 24 are known to have finished their education and to have gone onto establish careers. In some cases, the contextual challenges of economic downturn and revolution proved too great, but there were enough success stories to make this a remarkable episode. ${ }^{36}$

As we will see, the pool from which the Utrecht program drew its charges was the weakest of the three. Not surprisingly, then, completion rates and career paths of students in Delft and The Hague evidence a higher degree of success. Of the fifty orphans who

\footnotetext{
35 For The Hague, see Kernkamp (1910, pp. 492-494). It is worth quoting a sizeable excerpt: "Twaalf van de vlugste jongelingen uit het Burgerweeshuis worden hier opgenomen om te worden onderwezen in Frans, tekenen, schermen en dansen, maar vooral in mathematica en fysica, in welke laatste vakken zij onderwezen worden door een zekere la Faille, die, te oordelen naar het gesprek, dat ik met hem voerde, een geschikt en bekwaam man is voor dat doel. Alle theorie wordt zoveel mogelijk bekrachtigd door experimenten, waarvoor allerlei soorten van instrumenten gekocht worden, zonder er op te letten, of zij duur zijn of niet. La Faille heeft slechts te bestellen bij de beste instrumentmakers, die hij kent, en op voorwaarde, dat het instrument zo goed wordt, dat het volkomen beantwoordt aan zijn doel en de goedkeuring verwerft van de professoren Musschenbroek en Lulofs in Leiden, mogen zij zoveel daarvoor bedingen, dat zij met voordeel hun tijd en hun opmerkzaamheid daaraan kunnen wijden en geen vrees behoeven te koesteren, dat men hun afdingt. Jaarlijks is een som van 3,000 gulden bestemd voor het aankopen van instrumenten, zodat hier binnen weinig jaren de grootste verzameling bijeen zal zijn, die men ergens findt; bovendien is er meer geld beschikbaar voor instrumenten, wanneer in een of ander jaar meer dan 3,000 gulden nodig is. La Faille deed in onze tegenwoordigheid enige proeven met de instrumenten, die hij had, welker aantal reeds zo groot is, dat het hier te wijdlopig zou worden om ze op te sommen, want er zijn er reeds voor een bedrag van meer dan 10,000 gulden. Alle proeven gingen precies, zoals zij volgens de theorie moesten gaan".

For instrumental purchases at Leiden and Haarlem, see Clercq (1987, p. 171).

${ }^{36}$ For an overview of student successes, see Langenbach (1991), for Utrecht; Booy and Engel (1985), for Delft, and Hardenberg (1964), for The Hague.
} 
entered the Delft foundation by the end of the eighteenth century, for example, only eight did not complete their education successfully-one because of premature death. And while a small number (4) of Delft's graduates went onto work in various capacities on VOC ships and foreign colonies, most managed to practice their occupations in the Netherlands. These included carpenters and furniture makers, jewellers, surgeons, millwrights, teachers and surveyors (Booy and Engel 1985, pp. 291-295).

\subsection{Orphan Education and the Urge to Reform}

Successful Fundatie students owed much to their teachers, especially the mathesis (pure and applied mathematics and physics) instructors who served as unofficial directors of the three schools and who inspired their students both pedagogically and by example. From the start, these teachers worked to give substance to the meritocratic vision later articulated by Stijl that coupled personal development with national rebirth. As evidenced by the inaugural speech given in Delft by the man who would go onto be head teacher there for thirty years, this vision provided the very context in which the foundation's mission would be pursued. Johannes van der Wall used the occasion to make two points. He claimed first that physical labor alone could do little to advance society. Only an education stressing the arts and sciences could spur useful inventions and social happiness. Second, he praised the foundation's decision to establish separate schools for the most promising orphans rather than trying to teach the same program to all. Not every child is blessed with equal potential, he explained. Those with greater abilities deserve to be nurtured for the good of society (Wall 1760, pp. 21-22, 35-36). ${ }^{37}$

Before coming to Delft, Van der Wall taught structural engineering (bouwkunde) to military officers as he wrote a doctoral dissertation on navigation (ars navigandi) at Leiden University. Though tempted by offers to become professor at the universities of Leiden and Utrecht, Van der Wall stayed in Delft until his death in 1787. In addition to his work for the foundation, he examined captains and pilots for the East Indies Company, gave public lectures on mathematics and astronomy for the city of Delft and served as the city's inspector of public works. These tasks never eroded his dedication to his students, however. When good textbooks were unavailable, for example, Van der Wall wrote his own, on subjects ranging from practical geometry, mill construction and navigation to physics, geography and human anatomy. ${ }^{38}$ Further, he arranged the best apprenticeships possible for his students and followed their progress closely. In one case, he mentored the young man who would become his own successor, making sure that the foundation supported Abraham van Bemmelen until he completed his studies with Allamand at Leiden University (Booy and Engel 1985, pp. 58-64) In another case, Van der Wall shepherded Frederick Willem Conrad through an apprenticeship as surveyor, leading to his employment by the agency responsible for overseeing the Netherlands' rivers (the predecessor of today's Department of Water Management (Rijkswaterstaat)). Conrad ultimately became the agency's inspector general, following in the footsteps of Leiden University's physics professor Johan Lulofs (Winter 1988, p. 103).

\footnotetext{
37 It is striking to notice that Van der Wall repeatedly made use of metaphors drawn from water-management to speak of the foundation's mission.

38 Van der Wall apparently custom-made handbooks for his students that fit with their lessons in ways that available published texts could not do. They were never themselves published, nor have examples survived. What we know of them comes from reports Van der Wall made to the orphanage's board of regents. See especially "Rapport Van der Wall” (7/11/1783), Archief van de Fundatie van Renswoude \#60.
} 
Jacob Baart de la Faille showed similar dedication and ability in The Hague. While foundation director, he also taught mathematics to The Hague bureaucrats, showing his students by example how to combine theory with practice. Baart de la Faille fils, who taught by his father's side before becoming professor of mathematics and physics at the University of Groningen, paid homage to his father by posthumously publishing his book Verhandeling over de rekenkunsten (Lectures on Mathematics) in 1778 and by teaching his own courses in Groningen in a way that stressed practical application as much as theory (pp. 101-105; Hardenberg 1964, p. 162).

Utrecht was a different situation; so is the story of its head teacher. The Stadsambachtskinderhuis (Municipal Workers' Orphanage), from which Utrecht foundation students came, was established to house children who had nowhere else to go. Local Catholic orphanages wouldn't take them because they were born out of wedlock or were not fully Catholic. The more prestigious Burgerweeshuis (Burger Orphanage) would not accept them because their parents weren't municipal citizens. These were children from whom little was expected and to whom little was traditionally given. Unsurprisingly, none of them seemed appropriate candidates for the foundation when the first round of examinations was held. To solve this problem, a preparatory school was established to ready potential students for the foundation. Its director had to work closely with the foundation's head teacher to insure that things proceeded smoothly and effectively. In the case of the first director and head teacher, Dirk de West and Laurens Praalder, the results were striking both within and beyond the foundation. ${ }^{39}$

In 1773 Praalder used his spare time to help establish a society dedicated to applying the arts and sciences to social needs, the Genootschap 'Besteedt den tijd met Konst en Vlijt' (Society 'give time to art and industry'). ${ }^{40}$ De West became one of the society's first members. Not everyone was pleased with the society's unorthodox and un-hierarchical organization, however. Members seeking higher status for themselves and the society applied for and received a provincial patent that officially recognized them as the Provinciaals Utrechtsch Genootschap (Provincial Society of Utrecht). Not only was the society reorganized hierarchically, it redirected its purpose along more traditional lines. Praalder's vision of social improvement through public education was replaced by the desire for dilettantish gratification. ${ }^{41} \mathrm{He}$ and De West left the group.

They and their views soon found a new home however. This time it was De West who helped found the Utrecht chapter of the Maatschappij tot Nut van 't Algemeen (Society for Public Welfare), a soon-to-be nationwide society dedicated to the same ideals that motivated him and Praalder at the foundation and, previously, at the Genootschap 'Besteedt den tijd met Konst en Vlijt'. Initially a small society, Het Nut (as it was popularly called) developed into a network of local chapters where participants shared local interests and an increasingly national orientation that called for nationwide educational reform. The society's success can be gauged in two ways. First, it had fifty-two chapters by the turn of the century. Second, it provided the intellectual force behind a series of laws that organized

\footnotetext{
${ }^{39}$ Langenbach (1991, p. 102), makes the important point that, while the students in Utrecht overall seem to have achieved less than their fellows in Delft and The Hague, the success of the foundation in Utrecht has to be measured against the initial circumstances in which these orphans found themselves.

${ }^{40}$ For a quotation from the society's constitution, see Singels (1923, p. 30). For details regarding goals and membership structure see Mijnhardt (1988, p. 107).

41 We can see this by contrasting the work that Praalder and De West did at the foundation with the content of pedagogical guides written by another of the society's prominent members. de Perponcher (member of the Utrecht nobility) directed both his books $(1774,1782)$ exclusively to members of the upper classes.
} 
elementary education on a national basis in the Netherlands beginning in 1801 (Lenders, 1988, especially pp. 24-48).

Members of Het Nut were motivated by their commitment to creating a nation of moral citizens (Mijnhardt, 1988, pp. 259-294). We can recognize this retrospectively as a political goal in that it rested on a nationalist vision of the Netherlands - a vision in which all citizens received equal treatment under the law. In order to achieve this end, though, the society (like many other late eighteenth-century Dutch societies) declared itself officially apolitical. Discussions of party politics and partisan religion were barred from its meetings, which opened its membership to otherwise outspoken Patriots, loyal Orangists and men who were pragmatic enough to ride the rough waves of contemporary politics in order to get things done. (p. 266)

And get things done they did. A number of popular books on topics ranging from arithmetic and child-rearing to physics and natural history were published thanks to society efforts. And by cultivating good relationships with government officials, Nut members gained appointments as educational inspectors, overseeing a fledgling national school system based on their recommendations. The system's structure was laid out in a government commissioned report, written and published by Het Nut in 1796. The report called for a two-tiered program. A general curriculum was proposed for the nation as a whole, while a more advanced course of study was to be offered to those with "special" capacities. (Algemeene Denkbeelden 1796) The society embraced equal treatment under the law, therefore, but did not advocate social homogenization. Its proposal was explicitly meritocratic. Only those showing promise would be nurtured beyond the minimum. All students would be taught basic literacy, numeracy and morality; only a few would study science and languages. (p. 94) As Van der Wall had stated years before at the Fundatie van Renswoude's inauguration, society was moved by scientific enlightenment and not the brute force of physical labor. But only a few were capable of providing that intellectual power. The rest would serve the national good by internalizing the precepts of Christian morality and following their superiors' lead.

If the Netherlands remained a hierarchical society throughout the long eighteenth century by intellectual accord as well as practical circumstances, its educational programs and ideals helped give it form and direction. This should not be read, however, as an endorsement of the view that it was a society in which a growing gap separated the world of learning and culture from the practical concerns of work and technical development. ${ }^{42}$ Dutch universities continued to serve a variety of purposes under the unifying banner of utility while private initiative supported various schemes for redressing what was broadly perceived as the twin plagues of material and moral decline. Among these private initiatives were the amateur society Mathesis Scientiarum Genitrix and the Fundatie van Renswoude, both of whose programs reflected a facet of the Dutch Enlightenment's utilitarian ideal of disciplining nature and society for the public good. By paying special attention to morals, experimental physics, mechanics, applied mathematics and engineering, they prepared their orphans to serve a society of which they were made a part.

To round out this picture, two important qualifications must be added. First, Dutch faith in meritocracy seems less the outcome of a rise in individualism than the result of a commitment to the Netherlands as a national community. In this context, science and technology provided a medium for putting Dutch resources to profitable use, whether through engineering the landscape or educating orphans who showed promise. This form of 'nationalism' was not a product of revolution, but a longer-standing Dutch tradition that

$\overline{42}$ Compare Davids (1990) with Frijhoff (1981, pp. 287-288). 
had itself grown out of centuries of practical experience. It was, therefore, a sort of hybrid that mediated between an ideal and idealized national community on one hand and the realities of localism on the other. This helps to explain the co-existing pursuit of and commitment to reform, on one side, and resistance to the centralizing urges of programs put forth by both the Batavian and Napoleonic regimes.

Second, Dutch culture in the second half of the eighteenth century nurtured the myth of apolitical sociability, whereby various groups - aristocrats and middle class, Orangists and Patriots-could participate in the achievement of the same or similar goals despite their overt political differences. If revolution and war had a major impact on such activities, it was primarily to create financial distress and instability. Throughout it all, however, the concept of utility-liable to a range of overlapping meanings and applications-leant cultural continuity where social and political interests could not. ${ }^{43}$

\subsection{Postscript}

Both MSG and the Fundatie van Renswoude continue to exist to this day, though in rather different forms than that met in this essay. In general this has to do with, on one hand, historical developments in the field of Dutch education and, on the other hand, with the history of orphanages from which they drew their student-charges. As the nineteenth century progressed, secondary schools and institutions of higher education-including those that offered scientific technical courses in their curricula-increasingly appeared and became accessible to a broader range of young people. In conjunction with such broad developments in educational opportunities, programs run within orphanages ultimately became redundant. Faced with this situation, the Fundatie van Renswoude's three governing boards decided to take joint action in 1913. After establishing that they would not legally be held in violation of the foundation's original purpose, as laid out in the Vrijevrouw van Renswoude's will, they redirected the foundation's money to providing scholarships for promising students (not only orphans) who wanted to attend university.

Those responsible for MSG responded to the changing environment in a rather different way, both in terms of the kind of education offered and in terms of funding. As the nineteenth century progressed, surrounding technological and industrial developments increased the need for daytime training of boys to be augmented by courses in mathematics, physics and various sorts of engineering. To meet this demand, MSG organized an evening educational program, increasingly encouraged by the support of Leiden's cultural and intellectual establishment. By the end of the century, a program in electrical engineering was established, under the personal guidance of Leiden professor H. Kamerlingh Onnes. This longstanding link with the university both fed MSG's reputation and provided future opportunities for MSG students. By 1921, more than 450 students attended its evening school.

Following the end of World War Two a day school was also started to answer Leiden's ever-growing demand for technical studies. By 1966 almost 1,100 students were in attendance. Quite understandably, such dynamic developments could not have been financed by private subscription alone. Neither was it seen as desirable to maintain the schools as privately administered institutions, given the various government regulations to which they had to adhere. Alongside the historical transition from a small program, overseen by a private society (67 students received instruction in 1793) to a multi-tiered educational institution, it was almost inevitable that private funding would be replaced by

43 See note 8 above. 
government financing. Though it no longer sports its full Latin name, the fully public MSG Technical High School continues to offer technical education to teenagers in Leiden.

Open Access This article is distributed under the terms of the Creative Commons Attribution Noncommercial License which permits any noncommercial use, distribution, and reproduction in any medium, provided the original author(s) and source are credited.

\section{References}

Archief Heilige Geest Weeshuis, Leiden municipal archives.

Archief Koninklijk Genootschap 'Mathesis Scientiarum Genitrix', Leiden municipal archive.

Archief van de Fundatie van Renswoude Archive, Delft municipal archive.

Arsy, J. L. d'. (1682). Le Grand Dictionaire François-Flamende. J.J. Schipper, Amsterdam.

Beckers, D. (2003). Het Despotisme der Mathesis: Opkomst van de Propaedeutische Functie van de Wiskunde in Nederland 1750-1850. Hilversum: Uitgeverij Verloren.

Bierens de Haan, J. (1952). Van Oeconomische Tak tot Nederlandsche Maatschappij voor Nijverheid en Handel. Haarlem: Tjeenk Willink and Son.

Blok, P. J., \& Molhuysen, P. C. (1924). Nieuw Nederlandsch Biografisch Woordenboek, A.W. Sijthoff's Uitgevers-Maatschappij, Leiden.

Brender Brandis, G. (1796). Algemeene Denkbeelden over het Nationaal Onderwijs, ingeleverd in den jaare 1796, van ween de vergadering van hoofdbestuurders der Nederlandse Maatschappij: Tot Nut van't Algemeen, Amsterdam.

Chisick, H. (1981). The limits of reform in the enlightenment: Attitudes toward the education of the lower classes in eighteenth-century France. Princeton: Princeton University Press.

Daston, L. (1999). Afterword: The ethos of enlightenment. In W. Clark, J. Golinski, \& S. Schaffer (Eds.). The sciences in enlightened Europe (pp. 495-504). Chicago: University of Chicago Press.

Davids, C.A. (1990). Universiteiten, Illustre Scholen en de Verspreiden van Technische Kennis in Nederland, Eind 16e-Begin 19e Eeuw. Batavia Academica VIII:3-34.

Davids, C. A. (2005). Shifts of technological leadership in early modern Europe. In C. A. Davids \& J. Lucassen (Eds.). A miracle mirrored: The Dutch Republic in European Perspective. Cambridge: Cambridge University Press.

de Booy, E. P., \& Engel, J. (1985). Van Erfenis tot Studiebeurs. De Fundatie van de Vrijvrouwe van Renswoude te Delft. Opleiding van Wezen tot de Vrije Kunsten in de 18de en 19de Eeuw. De Fundatiehuizen. Bursalen in Deze Eeuw. Delft: Fundatie van Resnwoude.

de Clercq, P. (1987). In de Schaduw van 's Gravesande. Het Leids Physisch Kabinet in de Tweede Helft van de Achttiende Eeuw. Tijdschrift voor de Geschiedenis der Geneeskunde, Natuurwetenschappen, Wiskunde en Techniek, 10, 149-173.

de Perponcher, W. E. (1774). Instruction d'un père à son fils, Utrecht.

de Perponcher, W. E. (1782). Onderwijs voor kinderen, Utrecht.

Desaguliers, J.T. (1751). De Natuurkunde uit Ondervindingen opgemaakt, Amsterdam.

De Borger.

Florijn, J. (1802). Naamlijst en Korte Beschrijving van alle de Wis- en Natuurkundige Werktuigen, behoorende aan de Stichting van Wylen de Hoog Edele Welgeboorene Vrouwe, Vryvrouwe van Renswoude, in het Haagsche Burger Weeshuis, The Hague.

Frijhoff, W. (1981). La societé Néerlandaise et ses gradués, 1575-1814. Amsterdam: Rodopi.

Gaemers, C. (2004). Nalatenschap als Toekomst. De Fundaties van de Vrijvrouwe van Renswoude 1754-1810. Zutphen: Walberg Press.

Gravesande, W. 's. (1746). Elemens de physique, demontré et confirmé par des Experiences, Leiden.

Groenveld, S., Dekker, J. J. H., \& Willemse, Th. R. M. (Eds.). (1997). Wezen en Boefjes. Zes Eeuwen Zorg in Wees- en Kinderhuizen. Hilversum: Verloren.

Hake, B. (2004). Between patriotism and nationalism: Johan Hendrik Swildens and the 'Pedagogy of the Patriotic Virtues' in the United Dutch Provinces during the 1780s and 1790s. History of Education, 33, $11-38$.

Hardenberg, H. (1964). Het Burgerweeshuis voor Nederlands Hervormden te 's Gravenhage 1564-1964, Zuid-Hollandsche Boek- en Handelsdrukkerij, The Hague.

Hoker, M. d'. (1982). Arm Onderwijs voor Arme Kinderen. Bijdrage tot de Studie van het Lager Beroepsonderwijs in de Zuidelijke Nederlanden Tijdens de Achttiende Eeuw. Werkgroep Achttiende 
Eeuw, Onderwijs en Opvoeding in de Achttiende Eeuw: Verslag van het Symposium, Doesburg 1982, Holland University Press, Amstedam, pp. 103-111.

Jacob, M. (1997). Scientific culture and the making of the industrial west. Oxford: Oxford University Press. Johannes, G. J. (1995). De Barometer van de Smaak: Tijdschriften in Nederland 1770-1830. The Hague: SDU Publishers.

Kapossy, B. (2007). Republican political economy. History of European Ideas, 33, 377-389.

Kernkamp, G.W. (1910). Bengt Ferrner's Dagboek van Zijne Reis door Nederland in 1759 (Bijdragen en Mededeelingen van Het Historisch Genootschap XXXI).

Kloek, J., \& Mijnhardt, W. (2001). 1800: Blauwdrukken voor een Samenleving. The Hague: SDU.

Koerner, L. (1999). Linnaeus: Nature and nation. Cambridge: Harvard University Press.

Kooijmans, L. (1985). Onder Regenten: De Elite in een Hollandse Stad, Hoorn 1700-1780. Amsterdam: De Bataafsche Leeuw.

Lambert, A. (1971). The making of the Dutch landscape. London: Seminar Press.

Langenbach, M. (1991). Onbekend Talent. Leerlingen van de Utrechtse Fundatie van Renswoude, 1761-1795. Zutphen: Walburg Press.

Langenbach, M. (1995). Een Eigenzinnige Dame: Maria Duijst van Voorhout, Vrijevrouwe van Renswoude. Jaarboek Oud-Utrecht 85-112.

Lenders, J. (1988). De Burger en de Volksschool: Culturele en Mentale Achtergronden van een Onderwijshervorming, Nederland 1780-1850. Nijmegen: SUN.

Los, W. (2005). Opvoeding tot mens en Burger: Pedagogiek als Cultuurkritiek in Nederland in the Achttiende Eeuw. Hilversum: Verloren.

Lowood, H. (1991). Patriotism, profit, and the promotion of science in the German enlightenment: The economic and scientific societies, 1760-1815. London: Garland.

Luzac, E. (Ed.). (1759). Nederlandsche Letter-Courant.

Mijnhardt, W. (1988). Tot Heil van 't Menschdom. Culturele Genootschappen in Nederland, 1750-1815. Amsterdam: Rodopi.

Mijnhardt, W. (1998). The Dutch Republic as a town. Eighteenth Century Studies, 31, 345-349.

Mijnhardt, W., \& Kloek, J. (2001). 1800: Blauwdrukken voor een Samenleving. The Hague: Sdu Publishers.

Mornet, D. (1967). Les Origines intellectuelles de la Révolution française. Paris: A. Colin.

Nollet, J.A. (1759). Natuurkindige Lessen, door Proefneemingen bevestigd.

Palm, L. C. (Ed.). (1979). Alle de Brieven van Antonie van Leeuwenhoek, vol. 10. Lisse: Swets \& Zeitlinger.

Peeperkorn, L. (1985). Het Genootschap Mathesis Scientiarum Genitrix. Leiden: Private printing.

Ris, C. (1777). Ontwerp ter proeve ter oprigtinge eener Vaderlandsche maatschappy van Reedery en Koophandel, ter liefde van't Gemeenebest. Amsterdam: De Erve Houttuin.

Roberts, L. (1999). Going Dutch: Situating science in the Dutch enlightenment. In W. Clark, J. Golinski, \& S. Schaffer (Eds.). The sciences in enlightened Europe (pp. 350-388). Chicago: University of Chicago Press.

Roberts, L. (2004). The Arcadian apparatus: The introduction of steam engines into the Dutch landscape. Technology and Culture, 45, 251-276.

Roberts, L. (2006). P.J. Kasteleyn and the Oeconomics of chemistry. Ambix, 53, 255-272.

Roberts, L. (2007). Devices without borders: What an eighteenth-century display of steam engines can teach us about 'public' and 'popular' science. Science \& Education, 16, 561-572.

Roberts, L., Schaffer, S., \& Dear, P. (Eds.). (2007). The Mindful hand: Inquiry and invention from the late renaissance to early industrialisation. Amsterdam: Edita KNAW.

Rocard, M. (2007). Science Education Now: A Renewed Pedagogy for the Future of Europe. Office for Official Publications of the European Communities, Luxembourg.

Sewel, W. (1766). Volkomen Woordenboek der Nederduitsche en Engelsche Taalen. Amsterdam: Kornelis de Veer.

Shannot, S. (1736). Nieuw Woordboek der Nederlantsche en Latynsche Tale. Dordrecht: Joannes van Braam.

Singels, N. J. (1923). Uit de Geschiedenis van het P. U. G. (Provinciaals Utrechtsch Genootschap) 1773-1923. Utrecht: A. Oosthoek.

Smitkamp, H. (1950). Simon Stijl als Verlicht Geschiedschrijver. Bijdragen voor de Geschiedenis der Nederlanden, VI, 199-217.

Star, S. L., \& Griesemer, J. R. (1989). Institutional ecology, 'translations' and boundary objects: Amateurs and professionals in Berkeley’s museum of vertebrate zoology, 1907-1939. Social Studies of Science, $19,387-420$.

Stijl, S. (1774). De Opkomst en Bloei van de Republiek der Vereenigde Nederlanden, Amsterdam.

Titsingh, G. (1780). Bedenkingen over de schaarsheid van Zeevaarend Volk in het gemeen, en het verval onzer nationale zeevaart in het bizonder, Amsterdam. 
van Bemmelen, J. M. (1910). "Rede gehouden up de 106de Algemeene Vergadering, 23 April 1891", Jubileum: Uitgave en Programma der Feesten ter Gelegenheid van het 125 Jarig Bestaan van het Genootschap Mathesis Scientiarum Genitrix te Leiden. Leiden: MSG.

van Coeverden, F. W. W. H. (1983). Goor en Thomas Ainsworth. Uit de Geschiedenis van Twentsche Texteilnijverseid. Goor: Commissie Ainsworth-herdenking.

Van den Eerenbeemt, H. F. J. M. (1972). Het Huwelijk Tussen Filantropie en Economie: een Patriotse en Bataafse Illusie. Economisch-en Social-Historisch Jaarboek, 35, $28-64$.

Van den Eerenbeemt, H. F. J. M. (1977). Armoede en Arbeidsdwang: Werkenrichtingen voor 'Onnutte' Nederlanders in de Republiek 1760-1795. The Hague: Martinus Nijhoff.

van der Wall, J. (1760). Redenvoering ter plegtige inwijinge van het Kunst- en Kweekschool, volgens de laatste wille van wylen de Hoog Welgeboorne Vrouwe, Maria Duyst van Voorhout, vryvrouwe van Renswoude, Delft.

van Dijk, J. A. (1885). Toespraak: Het Eeuwfeest van het Genootchap Mathesis Scientiarum Genitrix te Leiden, P.W.M. Leiden: Trap.

van Mieris, F. (1784). Beschryving der stad Leyden. Amsterdam: Leiden.

van Musschenbroek, P. (1762). Introductio ad Philosophiam Naturalem, Leiden.

van Winter, P. J. (1988). Hoger Beroepsonderwijs Avant la Lettre. Bemoeiingen met de Forming van Landmeters en Ingenieurs by de Nederlandse Universiteiten van de Zeventiende en Achttiende Eeuw. Amsterdam: Noord-Hollandsche Uitgevers Maatschappij.

Wakefield, A. (2009). The disordered police state: German Cameralism as science and practice. Chicago: University of Chicago Press.

Zuidervaart, H. (2006). 'Meest Alle van Best Mahoniehout Vervaardigd'. Het Natuurfilosofisch Instrumentenkabinet van de Doopsgezinde Kweekschool te Amsterdam, 1761-1828. Gewina, 29, 81-112. 